\title{
Corrigendum: Out-of-body experiences associated with seizures
}

\section{Bruce Greyson *}

Division of Perceptual Studies, Department of Psychiatry and Neurobehavioral Sciences, University of Virginia Health System, Charlottesville, VA, USA

${ }^{*}$ Correspondence: cbg4d@virginia.edu

Edited and reviewed by:

John J. Foxe, Albert Einstein College of Medicine, USA

Keywords: epilepsy, seizures, out-of-body experiences, autoscopy, near-death experience

\section{A corrigendum on}

Out-of-body experiences associated with seizures

by Greyson, B., Fountain, N.B., Derr, L.L., and Broshek, D.K. (2014). Front. Hum. Neurosci. 8:65. doi: 10.3389/fnhum.2014.00065

In the Original Research Article "Out-ofbody experiences associated with seizures" (Frontiers in Human Neuroscience, February 2014, Volume 8, Article 65, doi: 10:3389/fnhum.2014.00065), the Acknowledgment of funding was inadvertently deleted. We wish to acknowledge with gratitude that our work was supported by the Fundação Bial (grant number 81/08).

Conflict of Interest Statement: The author declares that the research was conducted in the absence of any commercial or financial relationships that could be construed as a potential conflict of interest.

Received: 03 June 2014; accepted: 16 June 2014; published online: 10 July 2014.
Citation: Greyson B (2014) Corrigendum: Out-ofbody experiences associated with seizures. Front. Hum. Neurosci. 8:487. doi: 10.3389/fnhum.2014.00487

This article was submitted to the journal Frontiers in Human Neuroscience.

Copyright () 2014 Greyson. This is an open-access article distributed under the terms of the Creative Commons Attribution License (CC BY). The use, distribution or reproduction in other forums is permitted, provided the original author(s) or licensor are credited and that the original publication in this journal is cited, in accordance with accepted academic practice. No use, distribution or reproduction is permitted which does not comply with these terms. 